\author{
Review Article \\ www.ijrap.net (ISSN:2229-3566)
}

\section{A REVIEW ON GARBHADHAN VIDHI: A UNIQUE CONCEPT OF AYURVEDA} \\ Sudha Dansana ${ }^{1 *}$, Sujata Kadam ${ }^{2}$ \\ ${ }^{1}$ PG Scholar, Department of Stri Rog and Prasuti Tantra, All India Institute of Ayurveda, New Delhi, India \\ ${ }^{2}$ Professor and Head of the Department of Stri Rog and Prasuti Tantra, Dean, All India Institute of Ayurveda, \\ New Delhi, India
}

Received on: 06/01/21 Accepted on: 15/02/21

\author{
*Corresponding author \\ E-mail: dr.sudhadansana@gmail.com
}

DOI: 10.7897/2277-4343.120131

\begin{abstract}
Procreation is a religions duty enjoined on the Hindu to pay back his ancestral debt. Giving birth to a high-quality progeny is the demand of the today society and holistic Garbhadhan Vidhi as described in classical text fulfil this demand. Ayurveda describes simple methods to procure a healthy offspring and the planning of which starts from the selection of partner. These methods are popularised as Garbhadhan Samskara. In Ayurveda text Garbhadhan sacrament elaborated related to environmental factors, specific diet and cleansing measures which might influence the reproductive capabilities and have great physiological and psychological significance.
\end{abstract}

Keywords: Garbhadhan, Pre-conceptional, Samskara.

\section{INTRODUCTION}

Pre-conceptional care is a set of prevention and management interventions that aim to identify and modify biomedical, behavioural and social risk to women health or pregnancy outcome. Ayurveda has emphasized the concept of planned pregnancy through Garbhadhan Samskara to beget a Supraja i.e., healthy progeny by choice not by chance. Preventive care and prospective planning prior and after conception is the pillar of Pre-conceptional care. Pre-conceptional counselling is also considered as preventive obstetrics that helps to minimize complication of pregnancy by changing the physical and mental status of couple willing for pregnancy.

General conception care starts from selection of couple for marriage with specification to their age, health status and Gotra up to the purification of body, mind, soul that enhances the qualities of essential factors of conception, hence Preconceptional care is not only a biological process but also a biopsycho-spiritual process. A planned pregnancy by the couple after undergoing body purification and observing diets and certain rules mentioned in Ayurveda throughout pregnancy procures a desired progeny. This concept is practiced by many traditional Ayurvedic practitioners all over the India under the name of Garbha Samskara.

\section{Need of Garbhadhan vidhi}

In stressful society couple give more importance to carrier and not paying attention towards proper marital age, consanguinity of couple, suitable timing for intercourse, Dinacharya (Daily regimen), Ritucharya (Seasonal regimen) etc. As a result, they are facing many complications during the period of antenatal, intranatal, postnatal and are more prone to physical, psychological problems. The incidence of many neuro developmental disorders like ADHD (Attention Deficit Hyperactive Disorder), Autism can be overcome through a planned pregnancy. Hence it is the need of this era to revitalise the ancient method of Garbhadhan Vidhi to incorporate its benefit for mankind.

It is a review-based study; information pertaining to this study was primarily obtained from various Samhitas, research work, and scientific studies. Information regarding Garbhadhan Samskara has been compiled meticulously and the compiled data have been equated with the views of Ayurveda classics.

\section{Concept of Garbhadhan Samskara}

In Ayurveda, Samskara defines as "Gunantaradhaanam", means qualitative improvement of certain things by introducing the specific qualities. Garbhadhan Samskara is one among the Shodasha Samskara that described in Ayurveda. This is a method for procreating a worth full child, to endow future generations with good health, noble quality and high intelligence by improving the innate quality of mankind. Pre-conceptional and antenatal care influence on the offspring is discussed from the very beginning in Ayurveda. Parents Prakriti, age, consanguineous marriage, mental status while performing coitus, diet, ritual, regimen etc. during pregnancy have great impact on physical, psychological, spiritual constitution of foetus and these factors are well adorned with super qualities through the process of Garbhadhan Samskara.

Union of Shukra (Sperm), Shonita (Ovum) with Atma (Soul), Prakriti and Vikara leads to formation of Garbha. ${ }^{2}$ Man having healthy sperm copulates with a woman having healthy reproductive system i.e., ovum and uterus during Ritukala, then Dhaturupa Shukra excreted in the form of Beeja (Sperm). At this very time due to association of Satva (Mana), the Jivatma (Soul) enters in the Garbha. Due to intake of healthy diet by pregnant woman Garbha grows normally and gets delivered at appropriate time with all Indriya (Sensory organs) and fully developed body parts along with Matrujadi Shadbhavas (Procreative factors) 3 . 
The essential factors for conception are Ritu (Period near ovulation), Kshetra (Female reproductive system), Ambu (Water i.e., nourishing substance), Beeja (Ovum and Sperm). ${ }^{4}$

\section{- Ritu}

The period which is suitable for conception is called Ritukala. Conception depends upon the ovulation. Mature graafian follicle comes out from ovary during Ritukala. ${ }^{5}$

\section{- Kshetra}

Kshetra denotes to both Stri as well as uterus. A woman acts as a best aphrodisiac and stimulant for procreation. Uterus in female acts like field and sperm in man along with ovum in female acts like seeds which are sown. Creation of all being is due to the proper growth of seeds and the field. ${ }^{6}$

\section{- Ambu}

The blood and intercellular fluid or endometrial tissue with healthy and required nutrients without any abnormalities is quite helpful for the formation and development of the fetus.?

\section{- Beeja}

Beeja denotes to sperm (Pum-beeja) and ovum (Stri beeja ${ }^{8}$.

\section{Phases of Garbhadhan Vidhi}

- Phase-1- Purva Karma-Assessment of couple during marriage

- Phase-2- Pradhan Karma- Planning for conception

- Phase-3- Paschat Karma- Rituals after coitus

\section{Phase-1- Purva Karma- Assessment of couple}

Assessment of couple should be done before marriage to select the best couple for the conception. During selection of couple following factors should be kept in mind.

\section{- Age (Garbhadhan Yogya Kala)}

According to ancient Acharyas, the appropriate age of conception is 25 year for male and 16 year for female. ${ }^{9}$ At this age all the Dhatu (fundamental elements), the reproductive systems are fully formed and mature along with the couple attain the optimum physiologic functioning of the organs. Hence are capable for procreation. Both the partners are full of valour and vigour, the born child also possesses these qualities.

\section{- Atulya Gotra for Marriage}

Procurement of a healthy offspring begins with the selection of partner. For this ancient Acharyas have mentioned that the partner who will indulge in coitus for achieving a child should be of "Atulya gotra"10. It means they should be mutually of a different clan.

Acharya Chakrapani comments a male and a female from Atulya gotra should be married to each other. If they are from same Gotra then it is a sinful act according to the Dharma shastra. ${ }^{11}$

Several scientific studies have shown that consanguinity leads to death of infants before, during or immediately after birth, increased incidence of birth defects, genetic diseases including blinding disorders, blood cancer (acute lymphocytic leukaemia), and breathing problems for children at birth (apnoea), and increased susceptibility to disease etc. ${ }^{12}$

Consanguinity could increase the risk of inheriting any one of the 4968 (autosomal recessive) genetic diseases that could affect any part of the body from head to foot. ${ }^{13}$

The products of close marriages tend to produce an increase of the various types of genetic disorders such as birth defects, mental retardation, deafness and blindness. Most pregnancies do terminate prematurely or as abortions or miscarriages, which in itself are signs of an unhealthy pregnancy, perhaps one carrying a defect.

\section{Phase-2- Pradhan Karma- Planning for Conception}

After menstruation i.e., $4^{\text {th }}$ day onwards the couple should undergo certain purification process before conception. With following specific dietary regimen and rituals, they should happily go for coitus in proper time. The purification methods like Snehana (Oleation therapy), Swedana (sudation therapy), Vamana (emesis therapy), Virechana (purgation therapy), Basti (enema) are meant for incorporation of qualities in Shukra (sperm), Shonita (ovum), Garbhashaya (uterus) for procreation of best progeny. ${ }^{14}$

\section{- Snehana (Oleation) and Swedana (Sudation) Therapy}

Oleation therapy nourishes the all Dhatus. ${ }^{15}$ Snehana is indicated in treatment protocol of Artava and Shukra dushti. Snehana along with Swedana increases the normal function of Artava and Shukra.

\section{- Vamana (Emesis) Therapy}

Vamana therapy Cures Rasavaha Srotas Dushti, thus in turn improves the quality of Artava. It imparts the Agneyatva of Artava. As Vamana Karma cleanses micro-channels of body, corrects hormonal imbalance at Hypothalamus-Pituitary-Ovarian level. Thus, supports in conception.

\section{- Virechana Karma (Purgation)}

Virechana karma enhances the normal physiological action of Beeja (sperm and ovum) ${ }^{16}$

\section{- Basti (Enema)}

Basti improves the quality of sperm and ovum. It increases the quantity and morphology of sperm, nourishes the female reproductive system. Thus, helps in achieving a healthy progeny.

\section{- Nasya (Intranasal drug administration)}

Nasya should be given before the coitus for the achievement of conception. This is a part of Punsavana Karma. ${ }^{18}$

\section{- Diet}

Male partner is advised to take medicated ghee and milk (a group of medicines are used in Ghee/ milk which are sweet in taste) while female partners are asked to take sesame oil and Masha (sort of kidney beans) for one month. ${ }^{19}$ Because the Madhura Dravya increases Shukra Dhatu and Masha like Pittala Dravya increases Rakta Dhatu. 


\section{- Rituals before conception}

Performing Putreshti Yajna ${ }^{20}$ - Acharya Charaka and Kashyapa have described the detailed method of Putreshti Yajna which is actually a subject of sociology or religion. This is a sacred ceremony performed by couple to get a desired progeny. With performance of Putreshti Yajna, the couple go for coitus with chanting of Mantra (hymn). Particular hymn ${ }^{21}$ recited before coitus is for asking God to protect the foetus as well as for requesting God to give a courageous son or a child.

\section{- Proper time for coitus}

Visarga Kala (winter solstices) is suitable for conception, as it releases nourishing essence (Rasa) to living beings due to predominance of moon. From the month August to January are the usual months associated with Visarga Kala ${ }^{22}$

Ritu means a state of normal female menstruation cycle which indicates the proper time for conception. It ranges from $12^{\text {th }}$ to $16^{\text {th }}$ days of normal menstrual cycle. ${ }^{23}$ Intercourse should be in appropriate auspicious period of night. ${ }^{24}$

\section{- Clothing's during coitus}

Couple should wear white clothes; adorn him and her with garland of flowers.

\section{- Position during coitus}

For reception of Beeja the woman should lie in supine position, so that all the Doshas remain in their normal position. In Nubja (flexed position), Vayu gets aggravated and compress the Yoni. In Parshwagata (right lateral position), Kapha gets displaced and thus obstructs the Garbhashaya. In left lateral position, Pitta burns the Rakta (ovum) and Shukra (sperm). ${ }^{25}$

\section{- Contraindicated conditions for coitus}

The coitus should not be done with either man or woman having over eating, hunger, thirsted, chronically ill, anger, grief, fear, terror etc. These types of women either not conceive, if conceive then born child suffers from teratological abnormalities. ${ }^{26}$

\section{Phase-3- Paschat Karma- Rituals after coitus}

- After coitus couple should irrigate (genital organs) with cold water. ${ }^{27}$

- Maintain good mental health, as for achievement of conception happy mood is essential. (Saumanasya Garbhadharanam). ${ }^{28}$

- Avoid Garbhopaghatakara Bhavas (factors adversely affecting the foetus). ${ }^{29}$

\section{CONCLUSION}

A new Life begins with pregnancy because it gives birth to another life. Every parent wants their child to inherit good and moral qualities. Ayurveda gives natural, scientific and simplified methods of obtaining a desirable progeny. By adopting these simple methods of Garbha Samskara and following the rules, restrictions and specific regimen, one can procure a desirable, healthy, intelligent, beautiful progeny with strength, vigour and longevity.

\section{REFERENCES}

1. Agnivesha, Charaka Samhita, Vimana Sthana, Rasavimana Adhyaya 1/21. In Dr. Rajeshwara Datta Shastri, editor. Varanasi: Chaukhambha Bharati; 2013. p. 680.

2. Maharshi Sushruta. Sushruta Samhita, Sharira Sthana, Sharirasankhyavyakarana Sharira 5/13. In Kaviraja Ambikadutta Shastri, editor. Varanasi: Chaukhambha Sanskrit Sansthan Publisher; 2011. p. 54.

3. Agnivesha, Charaka Samhita, Sharira Sthana, Khuddikagarbhavakranti Sharira 3/3. In Dr. Rajeshwara Datta Shastri, editor. Varanasi: Chaukhambha Bharati; 2013. p. 851.

4. Maharshi Sushruta. Sushruta Samhita, Sharira Sthana, Sukrashonitasuddhi Sharira 2/35. In Kaviraja Ambikadutta Shastri, editor. Varanasi: Chaukhambha Sanskrit Sansthan Publisher; 2011. p. 19.

5. Maharshi Sushruta. Sushruta Samhita, Sharira Sthana, Garbhavakranti Sharira 3/5. In Kaviraja Ambikadutta Shastri, editor. Varanasi: Chaukhambha Sanskrit Sansthan; 2011. p. 26.

6. Pandit Girija Prasad Dwivedi. Manusmriti, Navama Adhyaya 9/33, $1^{\text {st }}$ ed. Lucknow: Newula Kishore Press; 1917. p. 323.

7. Maharshi Sushruta. Sushruta Samhita, Sharira Sthana, Garbhavakranti Sharira 3/29. In Kaviraja Ambikadutta Shastri, editor. Varanasi: Chaukhambha Sanskrit Sansthan; 2011.p. 33.

8. Maharshi Sushruta. Sushruta Samhita with Nibandha Sangraha commentary of Shri Dalhanacharya, Sukrashonitasuddhi Sharira 2/33. In Kaviraja Ambikadutta Shastri, editor. Varanasi: Chaukhambha Sanskrit Sansthan; 2011. p. 348.

9. Maharshi Sushruta. Sushruta Samhita, Sutra Sthana, Aturaupakramaniya Adhyaya 35/15. In Kaviraja Ambikadutta Shastri, editor. Varanasi: Chaukhambha Sanskrit Sansthan; 2011. p. 170.

10. Maharshi Bhela. Bhela Samhita, Sharira Sthana, Asamangotriya Sharira 3/1. In shri Abhay Katyayan, editor. Varanasi: Chaukhambha Surbharati Prakashan; 2009. p. 204.

11. Gujarati J, Pallavi K. A Pragmatic approach on Atulya gotra \& Consanguinity. researchgatenet.

12. Gujarati J, Pallavi K. A Pragmatic approach on Atulya gotra \& Consanguinity. researchgatenet.

13. Gujarati J, Pallavi K. A Pragmatic approach on Atulya gotra \& Consanguinity. researchgatenet.

14. Agnivesha, Charaka Samhita, Sharira Sthana, Jatisutriya Sharira 8/4. In Dr. Rajeshwara Datta Shastri, editor. Varanasi: Chaukhambha Bharati; 2013. p. 918.

15. Agnivesha, Charaka Samhita, Chikitsa Sthana, Vatavyadhi Chikitsa 28/81. In Dr. Rajeshwara Datta Shastri, editor. Varanasi: Chaukhambha Bharati Academy; 2011.p. 952.

16. Pandit Hemaraj Sharma. Kashyapa Samhita, Siddhi Sthana 2/5. Varanasi: Chaukhambha Sanskrit Sansthan; 2015. p. 225.

17. Agnivesha. Charaka Samhita, Siddhi Sthana, Kalpanasiddhi Adhyaya 1/31. In Dr. Brahmanand Tripathi, editor. Varanasi: Chaukhambha Surbharati Prakashan; 2011. p. 1167.

18. Maharshi Sushruta. Sushruta Samhita with Nibandha Sangraha commentary of Shri Dalhanacharya, Sukrashonitasuddhi Sharira 2/34, In Kaviraja Ambikadutta Shastri, editor. Varanasi: Chaukhambha Sanskrit Sansthan; 2011. p. 347.

19. Agnivesha. Charaka Samhita, Sharira Sthana, Jatisutriyasharira Adhyaya 8/4. In Dr. Rajeshwara Datta Shastri, editor. Varanasi: Chaukhambha Bharati Academy; 2011. p. 919.

20. Agnivesha. Charaka Samhita Sharira Sthana, Jatisutriyasharira Adhyaya 8/11. In Dr. Rajeshwara Datta 
Shastri, editor. Varanasi: Chaukhambha Bharati Academy; 2011. p. 922.

21. Agnivesha. Charaka Samhita, Sharira Sthana, Jatisutriyasharira Adhyaya 8/8. In Dr. Rajeshwara Datta Shastri, editor. Varanasi: Chaukhambha Bharati Academy; 2011. p. 921.

22. Agnivesha. Charaka Samhita, Sutra Sthana, Tasyashitiya Adhyaya 6/7. In Dr. Rajeshwara Datta Shastri, editor. Varanasi: Chaukhambha Bharati Academy; 2011. p. 137.

23. Bhavmishra. Bhava Prakash, Purva Khanda 3/2. In Prof. K. R. Srikanta Murthy, Vol-1, Varanasi: Chaukhambha Krishnadas Academy. p. 18.

24. Kaviraja Atrideva Gupta. Ashtanga Sangraha, Sharira Sthana, Putrakamiya Adhyaya 1/54. Varanasi: Chaukhambha Krishnadas Academy; 2007. p. 268.

25. Agnivesha. Charaka Samhita, Sharira Sthana, Jatisutriya Sharira 8/6. In Dr. Rajeshwara Datta Shastri, editor. Varanasi: Chaukhambha Bharati Academy; 2011. p. 920.
26. Agnivesha Charaka Samhita, Sharira Sthana, Jatisutriya Sharira 8/6. In Dr. Rajeshwara Datta Shastri, editor. Varanasi: Chaukhambha Bharati Academy; 2011. p. 920.

27. Agnivesha Charaka Samhita, Sharira Sthana, Jatisutriya Sharira 8/6. In Dr. Rajeshwara Datta Shastri, editor. Varanasi: Chaukhambha Bharati Academy; 2011. p. 920.

28. Agnivesha. Charaka Samhita, Sutra Sthana, Yajjapurushiya Adhyaya 25/40. In Dr. Rajeshwara Datta Shastri, editor. Varanasi: Chaukhambha Bharati Academy; 2011.p. 469.

29. Agnivesha. Charaka Samhita, Sharira Sthana, Jatisutriya Sharira 8/21. In Dr. Rajeshwara Datta Shastri, editor. Varanasi: Chaukhambha Bharati Academy; 2011.p. 928.

\section{Cite this article as:}

Sudha Dansana and Sujata Kadam. A Review on Garbhadhan Vidhi: A Unique Concept of Ayurveda. Int. J. Res. Ayurveda Pharm. 2021;12(1):137-140 http://dx.doi.org/10.7897/2277$\underline{4343.120131}$

\section{Source of support: Nil, Conflict of interest: None Declared}

Disclaimer: IJRAP is solely owned by Moksha Publishing House - A non-profit publishing house, dedicated to publishing quality research, while every effort has been taken to verify the accuracy of the content published in our Journal. IJRAP cannot accept any responsibility or liability for the site content and articles published. The views expressed in articles by our contributing authors are not necessarily those of IJRAP editor or editorial board members. 